\title{
Road Maintenance Management in Kano State, Nigeria: Case Study of Kano Metropolitan
}

\author{
M. M. Farouq ${ }^{1}$, F.H. Anwar ${ }^{2}$, Z.B. Baba ${ }^{3}$, M.S. Labbo ${ }^{4}$, D.S. Aliyu ${ }^{5}$ \\ $1,2,3,4,5$ Department of Civil Engineering Kano University of Science and Technology Wudil, Nigeria
}

\begin{abstract}
In Nigeria Road transport system is the most important means of transportation as in many developing countries. Roads are the major connecting links of states, towns, cities and villages. Nigeria has the largest road network in West Africa and second largest road network south of the Sahara with an estimated road length of 193200 kilometres. The roads have to be maintained so as to prolong its life. Without maintenance, roads can quickly fall into disrepair leading to increased costs for road users in vehicle operation, time, reliability and safety. The aim of this study is to examine the road maintenance management of Kano metropolitan roads and the possible ways of improving it. This paper examined the types of road defect on Kano metropolitan roads, the factors that contributes to the road defects, the road user's satisfaction on the maintenance works carried out by KARMA and analysed the problems on road defect reporting system in KARMA. The study was conducted through questionnaires, interviews and maintenance report at the maintenance office. A total of 25 questionnaires for KARMA, KNUPDA and ministry of works personals and 53 set for the road user's were analysed using SPSS and Average Index. From the study, the types of road defect on Kano metropolitan roads are potholes, patching and utility cut patching/Reinstatement of utility openings (electricity, water, telecommunication etc.) and edge cracks. The factor that contributes to the road defects are structural failure due to poor design and construction, inadequate maintenance policy and standards and the traffic load and volume. Overall, the road user's satisfaction on the maintenance works carried out by KARMA are 'Not satisfied. The problems on road defect reporting system and documentation in KARMA is unsatisfactory.
\end{abstract}

Keywords: Kano Nigeria, Road maintenance, Road defects, Reporting system, User's satisfaction.

\section{Introduction}

The importance of transport infrastructure cannot be abandoned due to the role it plays in the economic, social, and state of all countries in the world. The success and prosperity of this sector achieved attracted other sectors to be included, and therefore there is a strong relation between growth in the transportation sector and the country's economic growth as a whole [1]. Transport infrastructure like all other technical facilities, needs maintenance and reconstruction so that it can serve its users' needs properly. The users' comfort and travel time are in proportional to the effectiveness of those works [2].

Likewise in Nigeria Road transport system is the most important means of transportation and indeed in many developing countries. This is because roads are the major connecting links of states, towns, cities and villages. It has been estimated that road transportation represents about $85 \%$ of passenger and delivery activities in Nigeria. It has been said that Nigeria has the largest road network in West Africa and second largest road network south of the Sahara with an estimated road length of 193200 kilometres [3]. The Nigerian road network comprises Federal roads, State roads and Local Government roads [4]. The problem of maintaining those roads has been given as one of the major factors leading to accidents, increasing road user cost and decreasing the economy of this nation. As Kano state is one of the major city in Nigeria and named as centre of commerce such problem of poor road network system has been affecting the economy of the state.

N. Okigbo, 2012 [5] from his study on the causes of highway failure in Nigerian highways listed out some of the factors that causes these failures and These factors were; poor design and construction, poor maintenance of already built highways, use of low quality materials in construction, poor workmanship and poor supervision of construction work and the applying of heavy traffic that were not meant for the road. Furthermore, he also suggest that the following will lead to highway failure such as; poor highway facilities, no knowledge base, in adequate sanction for highway failure, no local standard of practice, poor laboratory in situ tests on soil and weak local professional bodies in highway design, construction and management. S. Tarawneh and M. Sarireh, 2013 [6] from their study categorized some factors that contribute to the road deterioration and such factors are Effect of Cracks and Structural Failure, Effect of Standards/Specifications and Policy, Effect of Traffic Load and Volume, Properties and Effect of Construction Conditions, Effect of Drainage System and Ground Water, Aggregate Properties, Effect of Alignment and Geometry of Road, Flexible Pavement Layers Thickness, and Effect of Pavement Width. B. L. Pflug and S. Oesch, 1986 [7] Pointed out that the highway network represents a huge investment and each year the financial restraints on highway maintenance become 
more critical. Similarly in the report of the executive meeting of Kano state government it was estimated that the amount of money spent on road maintenance in just Kano metropolitan is almost a millions of naira [8], which is quite a lot. Therefore the need to find out rational management system for highway maintenance is important. One of these systems is to find solutions on how to carry carryout systematic and on-line reporting and inspection systems for the collection of the characteristics data relative to the deterioration of the highways.

Traditionally road engineers periodically monitor the current conditions of road systems to detect any defects and then commence the appropriate M\&R activities. This procedure is complex and prone to human error. Despite this criticism on tradition method of reporting and documentation, Kano State Road Maintenance Agency (KARMA) and Kano State Urban Planning and Development Agency (KNUPDA) still relay on this method due to the limited technology in the state and also in the Nigeria at large. Furthermore, with the advancement of technology nowadays in developed countries many system of reporting are now in place, example Mobile Road Monitoring and Reporting System and Web-Based Road Monitoring and Reporting System which simplify the traditional way of monitoring highway defects.

Therefore, the main purpose of this study is to assess the level maintenance management in Kano State Road Maintenance Agency (KARMA) in term of the repair work as well as the reporting system in the agencies. Earlier research either restricted on finding the types of defect and their factors contribute, the repair methods while ignoring the root source which is the reporting system that causes delay whereby considerable increase in the defect may arise because most of the defect are due to natural event such as rain, temperature etc. But this research takes an integrated approach of both aspects in order to find out the tentative solutions to the problems in road maintenance of the agencies.

\subsection{Problem Statement}

Huge sums of money have been spending into road maintenance in Kano state [8]. The road is currently under the maintenance of Kano road maintenance management agency (KARMA) together with Kano Urban Planning and Development Authority under the direct supervision of the state ministry of works, housing and transport. However, these roads have been affected by a number of problems like presence of potholes, washing away of pavements, cracks, depression, shoving etc., along most of Kano metropolitan roads, with the major ones being, inadequate or poor drainage system, poor maintenance culture and inadequate finance [9]. Other problems are poor maintenance culture, poor reporting and documenting system, and improper procurement method and this have significantly reduced the utility of the roads as shown in figure 1 below.
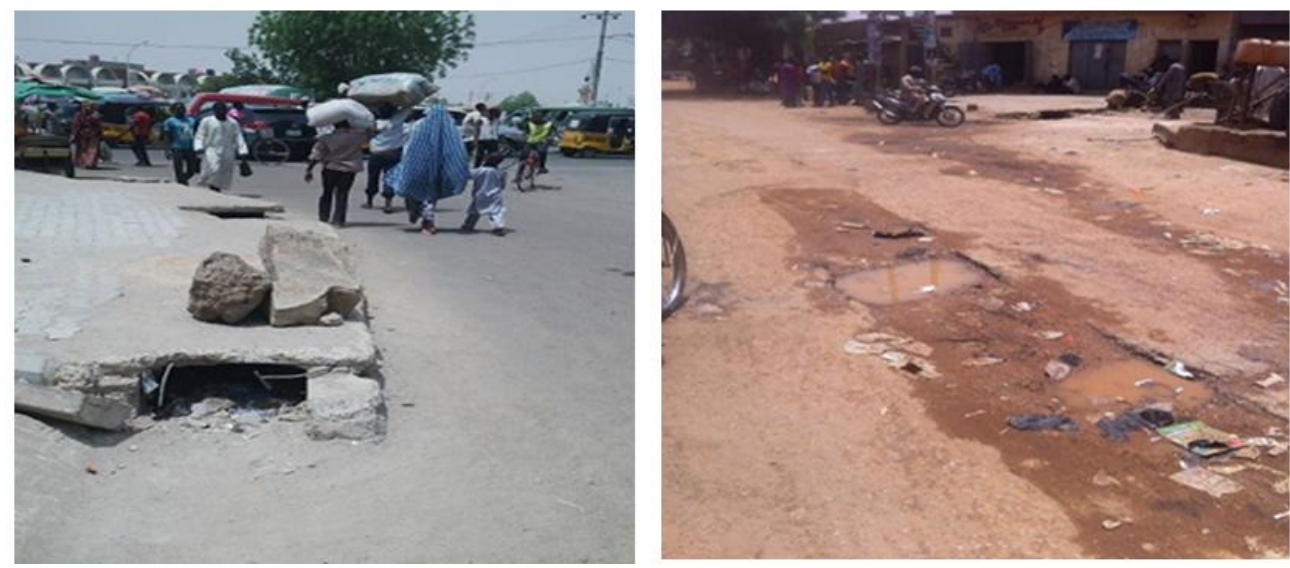

Figure 1: Dan'agundi Road and Rimi Market road (source visual inspection)

Kano state as a most populous and leading in commercial centre in Nigeria with many people leaving in the metropolitan and with the above problems still stand without effective maintenance management [10]. These have made it difficult to road users in enjoying the utility of the roads and also affect the economy of the state.

Therefore, this study of road maintenance management will guide the agency in finding the effective way of maintaining and managing the roads. The research was conducted in Kano metropolitan roads, specifically those roads in urban area which covers $137 \mathrm{~km}^{3}$ and comprises of eight local government area with the population of around 3 million [11]. The scope of the research for achieving the objectives focused on the maintenance work and supervision done by Kano State Road Maintenance Agency (KARMA). Attention was given only on the road pavement maintenance excluded others categories of road maintenance facilities such as culvert, road furniture's, shoulders and median etc. 


\subsection{Challenges in data collections}

\section{Research Methodology}

One of the defining issues of the Kano state road network is the lack of reliable data. For example, on 18/January/2015 the director of Kano state road maintenance agency stated that, between January and December 44 township roads were rehabilitated in Kano state [12], but yet the data that can show all this is still unavailable in the ministry. It is evident that there is a need to utilize data that can be supported, and where assumptions have been made, they have been done so with logic and regional context. As such, where possible, data was taken from the literature, questionnaires, interviews and observation. A visit was made to some commercial motor garages in Kano metropolitan and interacted with daily users of the roads.

\subsection{Methodology flow chart}

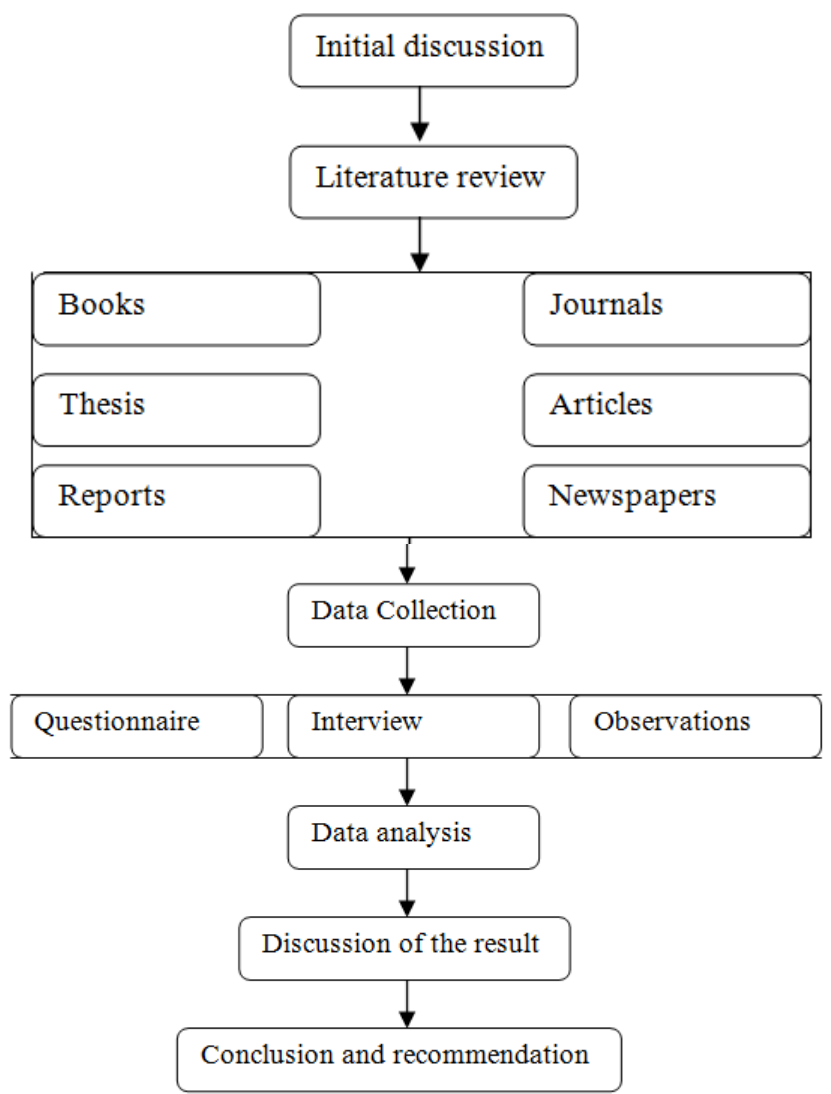

Figure 2 Flow chart of research methodology

\subsection{Survey questionnaire}

Two questionnaires survey forms were designed for road maintenance agencies and road users to gather information and opinion of agencies responsible for road maintenance in the Kano metropolitan (KARMA, KNUPDA, and Ministry of work) and the road users (the general public and bus drivers etc.). This survey aims to determine the types of defect occurred along Kano metropolitan roads and the possible factors that contribute to these defects, to determine the problems of defect reporting system in KARMA agency, and to evaluation of the maintenance and repair works carry out by KARMA agency through road user's satisfaction.

\subsection{Data analysis}

The data analysis is the stage where all the result including data and information from the document study and achieved data, interview, site visit and questionnaire survey were analysed to produce the finding of the study. The questionnaire survey was analysed using average index method. According to Abd. Majid and McCaffer (1997), the average index is calculated based on the following formula.

$$
\text { Average index }=\frac{\sum \mu \mathrm{Nn}}{N} \text {. }
$$

Where

$\mu=$ weight given to each factor by respondent (1 to 5)

$\mathrm{n}=$ frequency of the respondent 
$\mathrm{N}=$ total number of the respondent

So the designed application of average index in the questionnaire would be as below

Table 1 Likert scale for agreement toward each statement

\begin{tabular}{|l|l|l|}
\hline scale & Level of agreement & Index \\
\hline $\boldsymbol{\mu 1}=\mathbf{1}$ & Strongly Disagree & $1.00 \leq$ Average Index $<1.50$ \\
\hline $\boldsymbol{\mu 2}=\mathbf{2}$ & Disagree & $1.50 \leq$ Average Index $<2.50$ \\
\hline $\boldsymbol{\mu 3}=\mathbf{3}$ & Neutral & $2.50 \leq$ Average Index $<3.50$ \\
\hline $\boldsymbol{\mu 4}=\mathbf{4}$ & Agree & $3.50 \leq$ Average Index $<4.50$ \\
\hline $\boldsymbol{\mu 5}=\mathbf{5}$ & Strongly agree & $4.50 \leq$ Average Index $\leq 5.00$ \\
\hline
\end{tabular}

\subsection{Reliability test}

The reliability test of Cronbach's Alpha coefficient was used to determine the reliability of the survey response data. The detail information about Cronbach's coefficient for reliability test of survey's response is given below [13].

Table 2 Reliability ranges

\begin{tabular}{|l|l|}
\hline Cronbach's Alpha & Internal consistency \\
\hline $\boldsymbol{\alpha} \geq 0.9$ & Excellent \\
\hline $0.9>\boldsymbol{\alpha} \geq 0.8$ & Good \\
\hline $0.8>\boldsymbol{\alpha} \geq 0.7$ & Acceptable \\
\hline $0.7>\boldsymbol{\alpha} \geq 0.6$ & Questionable \\
\hline $0.6>\boldsymbol{\alpha} \geq 0.5$ & Poor \\
\hline $0.5>\boldsymbol{\alpha}$ & Unacceptable \\
\hline
\end{tabular}

\section{Result And Discussions}

The reliability on the data obtained from professional questionnaire was found to be 0.737 as shown in fig 3.0, so according to Cronbach's this data is acceptable. Furthermore, the reliability on road user's data was found to be 0.801 as shown in fig 4.0 which according to Cronbach's this data is good and acceptable.

Table 3.0 Reliability result (professional data)

\begin{tabular}{|l|l|}
\hline Reliability Statistics (professional data) \\
\hline Cronbach's Alpha & N of Items \\
\hline .737 & 43 \\
\hline
\end{tabular}

Table 4.0 Reliability result (road user's data)

\begin{tabular}{|l|l|}
\hline Reliability Statistics (road users) \\
\hline Cronbach's Alpha & N of Items \\
\hline .801 & 36 \\
\hline
\end{tabular}

\section{Analysis Of The Questionnaire Data For Professionals}

\subsubsection{Background study of the respondent}

Background of the respondent's was classified into 4 groups, namely, nature of agency, current position, highest qualification and working experience.

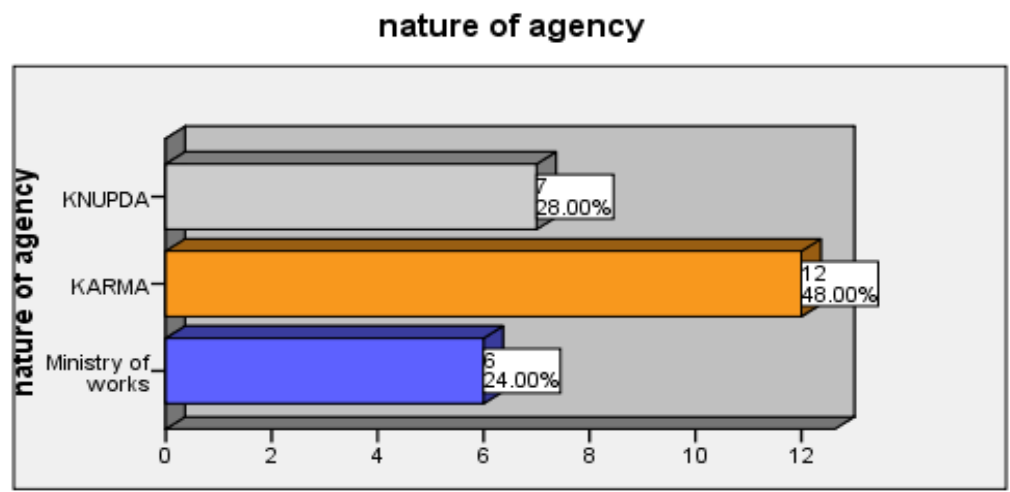

Figure 1 nature of the agency 
Referring to Fig 1 out of 25 respondents, 6 or $24 \%$ respondents are from Ministry of works Housing and transport, 12 or $48 \%$ of the respondent are from KARMA which is the targeted agency, and the remaining 7 or $28 \%$ were from KNUPDA.

\subsubsection{Highest qualification}

Highest qualification

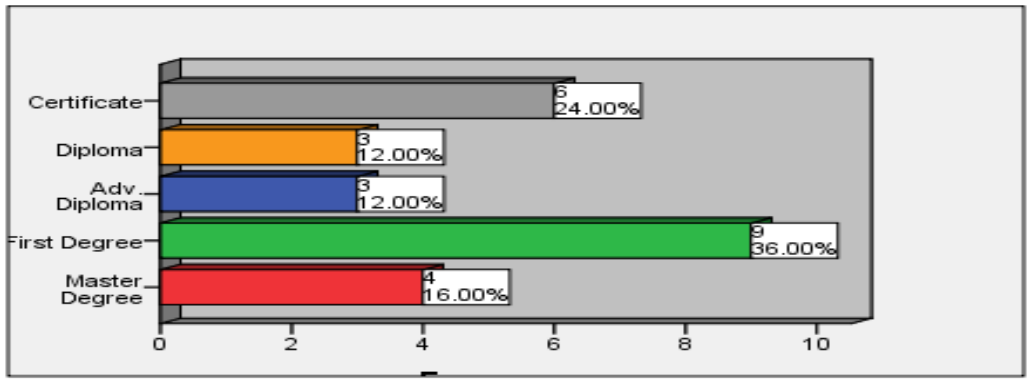

Figure 2 highest qualifications of the respondents

The collected questionnaire were also classified based on the respondent's qualification as shown in Fig 2, 9 or $36 \%$ of the respondent have first degree qualification which the highest, followed by certificate holders with 6 or $24 \%$ respondents while 4 or $16 \%$ of the respondent have master's degree and 3 or $12 \%$ for both advance diploma and diploma holders among the respondents.

\subsubsection{Working experience}

Working experience

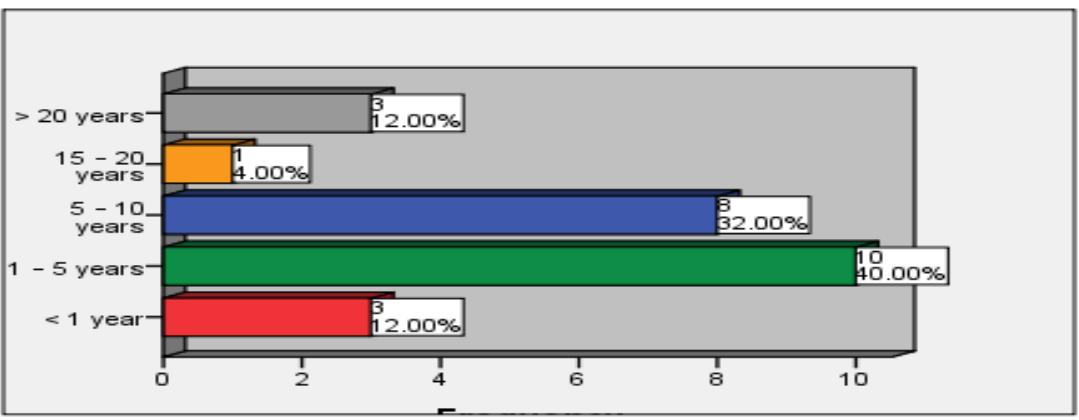

Figure 3 working experience of the respondent

The questionnaire were also classified in term of the respondent's working experience which is measured in term of working years' experience as shown in Fig 3 or $12 \%$ of the respondents have a working experience of less than a year, 10 or $40 \%$ of the respondents have a working experience of about 1 to 5 years which are the highest percentage, 8 or $32 \%$ respondents have 5-10 years working experience, 1 or $4 \%$ of the respondent have a working 15-20 years which is the least among the respondents, and 3 or $12 \%$ of the respondents have above 20 years working experience

4.3 Finding of objective 1: To examine the types of road defect on Kano metropolitan roads.

4.3.1 Types of cracks commonly occurred/observed on the road surface

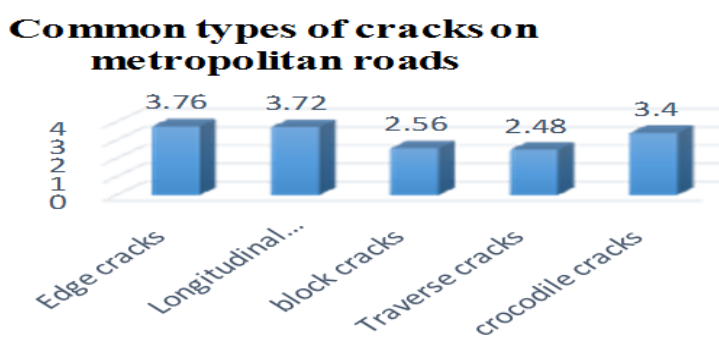

Figure 4 common types of cracks occurred 
From the response of the respondent as shown in Fig 4, it can be concluded that edge cracks and longitudinal cracks are the most often occurred or observed on Kano metropolitan roads with average index of the respondents of 3.75 and 3.72 respectively, however block cracks and crocodile cracks are sometimes occurred or observed with average index of 2.58 and 3.4 respectively. The least is traverse cracks which seldom occurred or observed with average index of the respondent of 2.48 .

\subsubsection{Common types of surface deformation occurred on the road surface}

\section{Common types of surface deformation on metropolitan roads}

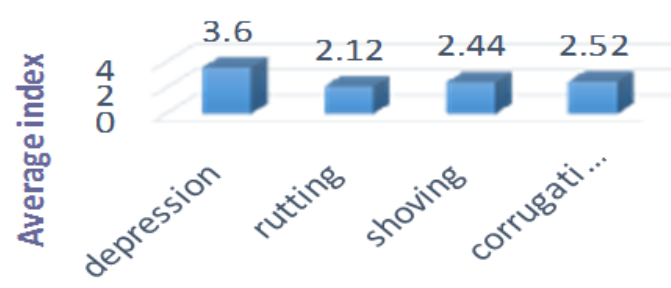

Types of surface deformation

Figure 5 common types of surface deformation occurred

From Fig 5 it can be judged that depression is the most open occurred or observed on road surface with average index of 3.6, whereas corrugation is sometimes occurred with average index of 2.52. Furthermore, rutting and shoving are seldom occurred with average index of 2.12 and 2.44 respectively.

\subsubsection{Common types of surface defects occurred on the road surface}

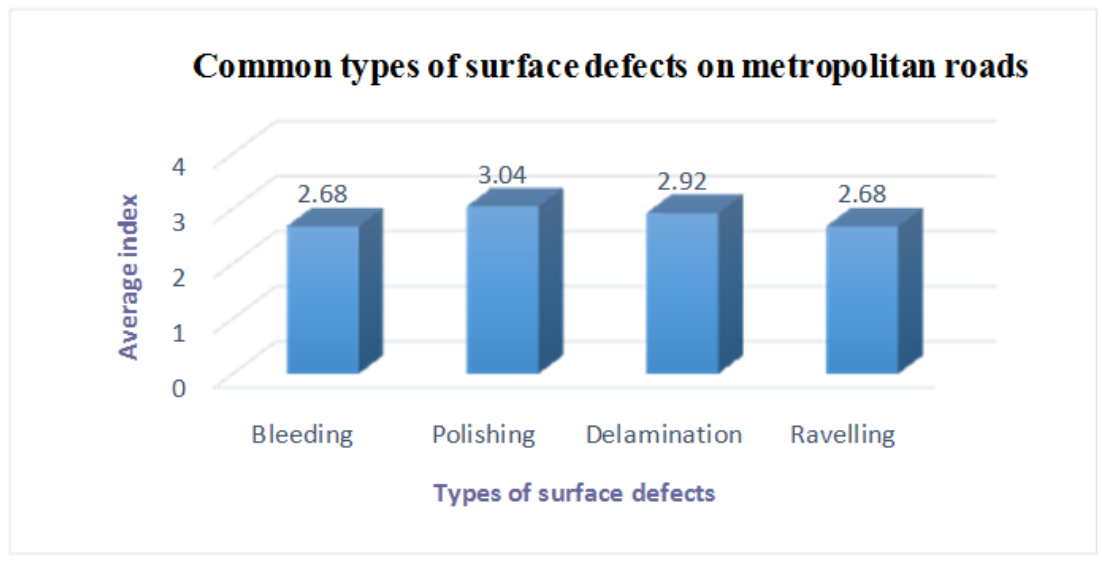

Figure 6 common types of surface defects occurred

From Fig 6 it can be concluded that polishing is must occurred with the highest average index of 3.04 followed by delamination with 2.92 average index, and both bleeding and revelling with 2.68 average index. Although both of the factors falls under the range of sometimes occurred. This means that both of the above defect are been seen sometimes along most of Kano metropolitan road

\subsubsection{Potholes}

It can be seen from Table 5as shown below. Potholes is often occurred or observed along road surface with average index of 4.00 .

Table 5 Result of the identification of pothole

\begin{tabular}{|l|l|l|l|l|l|l|l|}
\hline & never & seldom & sometimes & often & always & average index & rating scale \\
\hline Pothole & 1 & 0 & 4 & 13 & 7 & 4 & often \\
\hline
\end{tabular}




\subsubsection{Patching}

It can be seen from table 6 as shown below. Patching is often occurred or observed along road surface with average index of 3.52 .

Table 6 Result of the identified patching

\begin{tabular}{|l|l|l|l|l|l|l|l|}
\hline & Never & Seldom & Sometimes & Often & Always & $\begin{array}{l}\text { Average } \\
\text { index }\end{array}$ & Rating scale \\
\hline $\begin{array}{l}\text { Patching and utility cut } \\
\text { patching/Reinstatement of utility } \\
\text { openings (electricity, water, } \\
\text { telecommunication etc.) }\end{array}$ & 0 & 3 & 10 & 8 & 4 & 3.52 & Often \\
\hline
\end{tabular}

4.4 Finding of objective 2: To explore the factors that contributes to the road defects 4.4.1 Summary of the factors contribute to the road deterioration and deformation

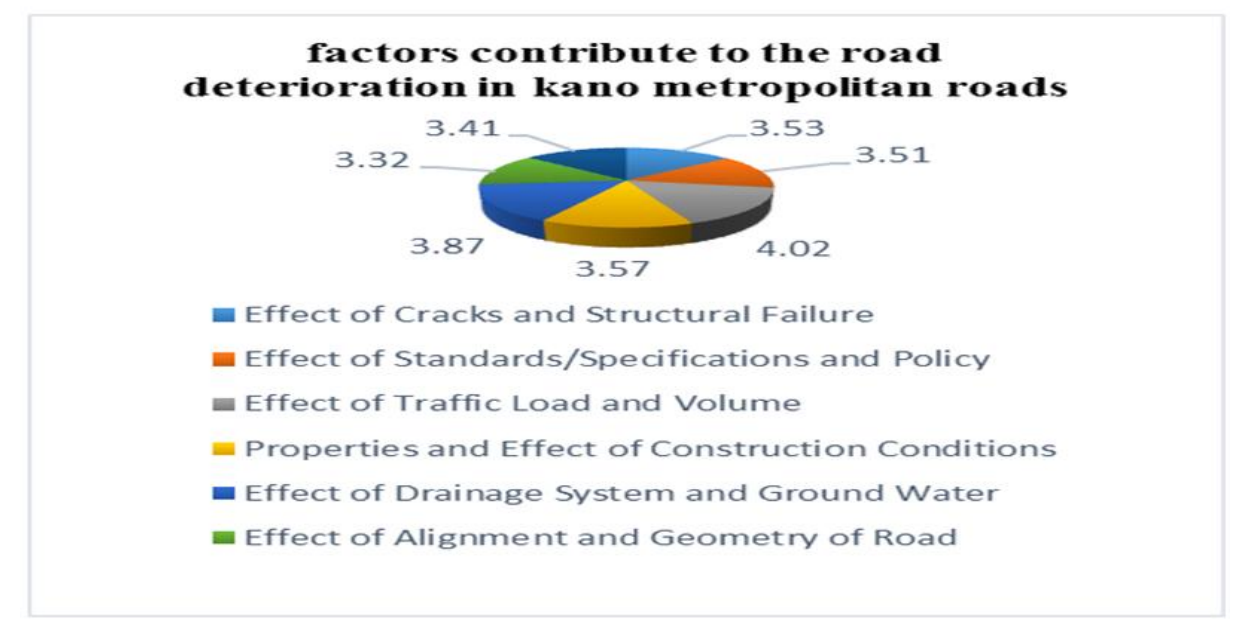

Figure 7 factors contribute to the road deterioration

Fig 7 presents the rank for the group factor from the respondent view of point. The most significant factor that contribute to the road deterioration as par as respondent point of view are: Effect of Traffic Load and Volume has the maximum rank of 4.02 followed by Effect of Pavement Width with average index of 3.87, then the effect of Properties and Effect of Construction Conditions with average index of 3.57, Effect of Cracks and Structural Failure has average index of 3.53, Effect of Standards/Specifications and Policy has average index of 3.51, Effect of Drainage System and Ground Water has average index of 3.41, while the effect of Alignment and Geometry of Road has the minimum average index of 3.32. Only those factors that are agreed or highly agree by the respondent are considered as significant and conclusion is made only on these factors.

Table 7 factors contribute to the deterioration of Kano metropolitan roads

\begin{tabular}{|l|c|l|}
\hline Factors & Average index & Rating scale \\
\hline $\begin{array}{l}\text { Effect of Cracks and Structural } \\
\text { Failure }\end{array}$ & 3.53 & Agree \\
\hline $\begin{array}{l}\text { Effect of Standards/Specifications } \\
\text { and Policy }\end{array}$ & 3.51 & Agree \\
\hline Effect of Traffic Load and Volume & 4.02 & Agree \\
\hline $\begin{array}{l}\text { Properties and Effect of Construction } \\
\text { Conditions }\end{array}$ & 3.57 & Agree \\
\hline $\begin{array}{l}\text { Effect of Drainage System and } \\
\text { Ground Water }\end{array}$ & 3.87 & Neutral \\
\hline $\begin{array}{l}\text { Effect of Alignment and Geometry of } \\
\text { Road }\end{array}$ & 3.32 & Neutral \\
\hline Effect of Pavement Width & 3.42 & \\
\hline
\end{tabular}

4.5 Finding of objective 3: To evaluate the road user's satisfaction on the maintenance works carried out by KARMA

4.5.2 Road user's satisfaction level with riding/travel comfort on Kano Metropolitan Roads 


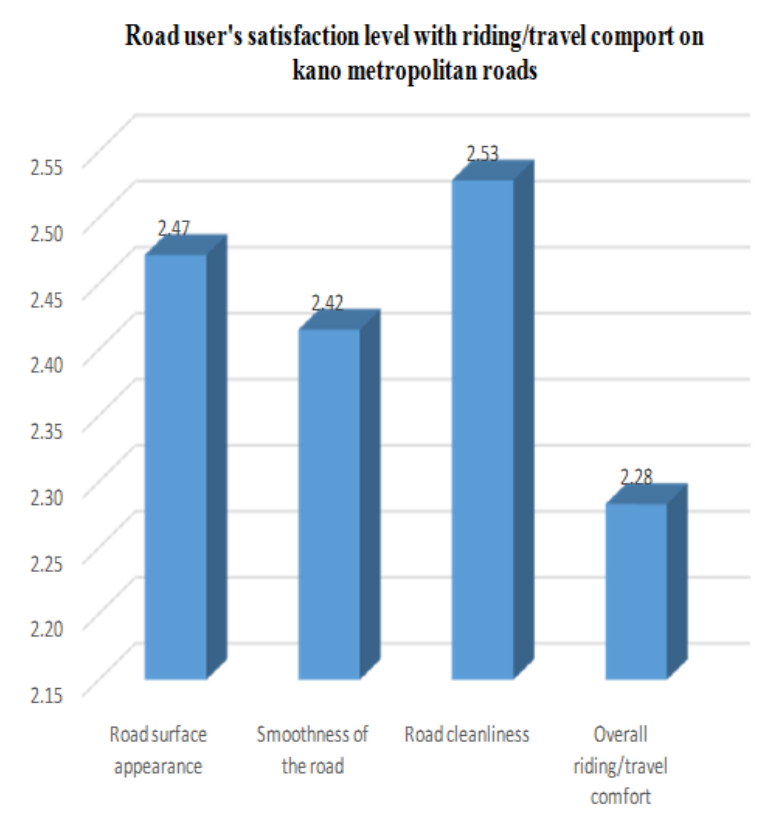

Figure 8 Road user's satisfaction level with riding/travel comfort on Kano Metropolitan Roads

From figure 4.5.2 it can be concluded that the respondent are not satisfied with road surface appearance with average index of 2.47 , so also majority of the respondent dissatisfied with the smoothness of the road with the average index of 2.42 this can be prove by referring to the objective one result which shows that pothole, patching and other road deterioration are often occurred or observed on Kano metropolitan roads. However most of the respondent somewhat satisfied with the road cleanliness this is as the result of the provision of Kano state refuse management and sanitation board (REMASAB) by the government under the ministry of environment which has the responsibility of cleaning the roads. In conclusion the overall riding/travel comfort with average index of 2.28 shows that majority of the respondent dissatisfied with overall riding of the roads.

4.5.3 Road user's satisfaction level with the performance of Road maintenance and repair works carry out by Kano Road Maintenance Agency (KARMA).

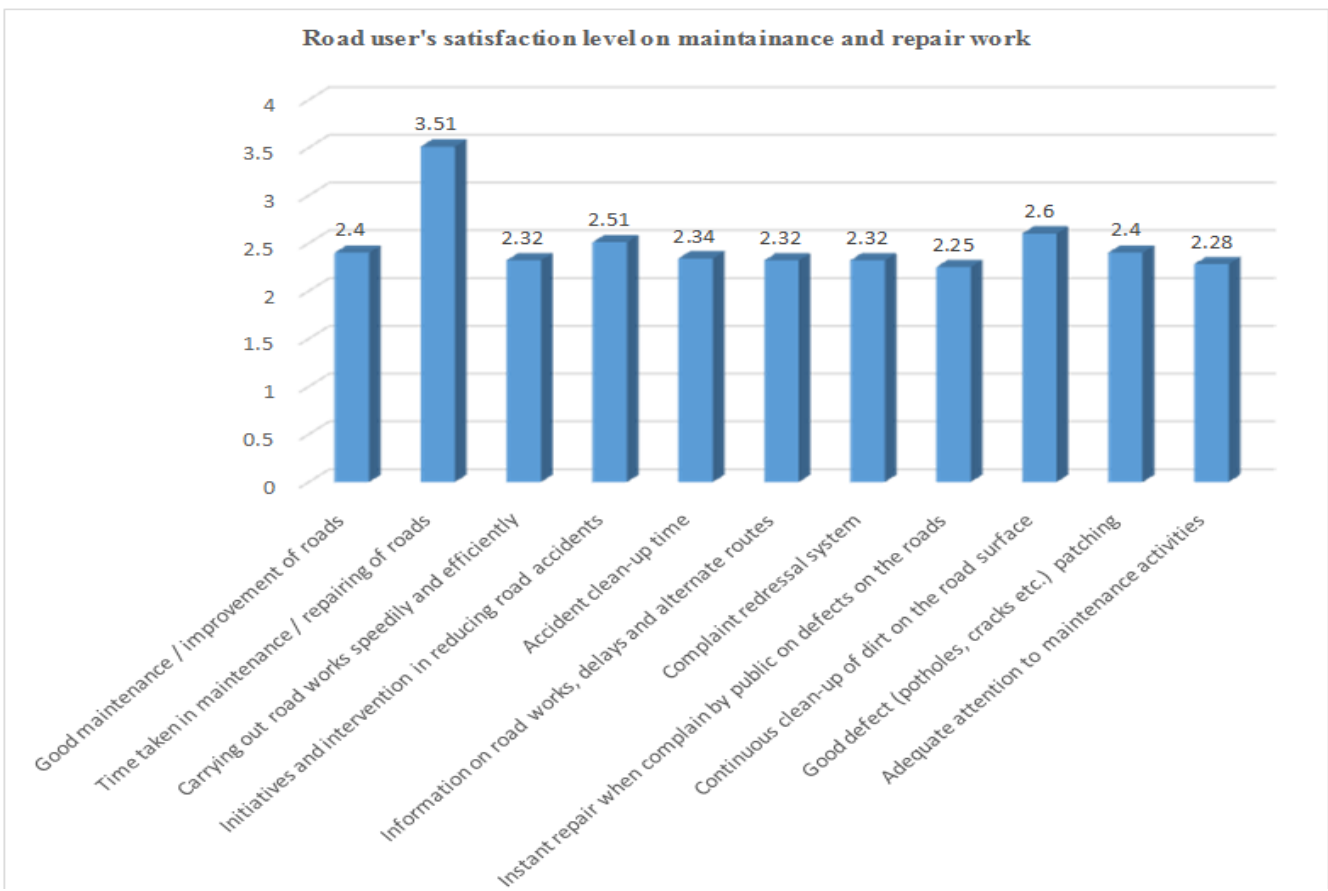

Figure 8 Road user's satisfaction level with the performance of Road maintenance and repair works carry out by Kano Road Maintenance Agency (KARMA). 
Figure 8 above shows that nearly $54.72 \%$ of the road-users responded that Good maintenance / improvement of roads as somewhat dissatisfied, whereas nearly $20.74 \%$ of the respondent are neither satisfied nor dissatisfied while only $11.32 \%$ of the users are satisfied. Average index of the overall satisfaction of the Good maintenance / improvement of roads was found to be 2.4 which believed to be unsatisfactory to the respondents. However it was found that $32.1 \%$ of the respondents satisfied with time taken in maintenance / repairing of roads which is the highest with the average index of 3.51, from the respondent response the average index on the question whether the agency carrying out its work speedily and efficiently was found to be 2.32 , this clearly shows that the respondent are not satisfied with the agency's work on this part.

Furthermore, accident clean-up time with average index 2.34, Information on road works, delays and alternate routes with average index 2.32 , Complaint redressal system with average index 3 , Instant repair when complain by public on defects on the roads with average index 2.32, Good defect (potholes, cracks etc.) Patching with average index 2.25, and adequate attention to maintenance activities with average index 2.28 , all of the index value shows that the respondent are not satisfied with initiative and works carryout by the agency. Finally the average index of the of the road user's over the overall satisfaction level of the performance of Road maintenance and repair works carry out by Kano Road Maintenance Agency (KARMA) was found to be 2.48 as shown in table 8 below. This means that the road users are not satisfied with the overall performance on the maintenance and repair by KARMA agency.

Table 8 satisfaction on KARMA maintenance and repair works

\begin{tabular}{|c|c|c|c|c|c|c|c|}
\hline & 常兽 & 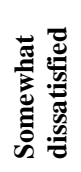 & 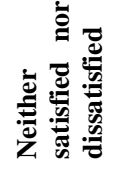 & 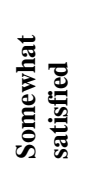 & 을 웝 & 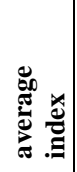 & 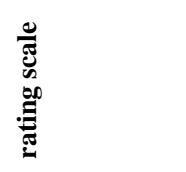 \\
\hline $\begin{array}{l}\text { Good maintenance } / \\
\text { improvement of roads }\end{array}$ & 6 & 29 & 11 & 5 & 2 & 2.40 & $\begin{array}{l}\text { Somewhat } \\
\text { dissatisfied }\end{array}$ \\
\hline $\begin{array}{l}\text { Time taken in } \\
\text { maintenance / repairing } \\
\text { of roads }\end{array}$ & 3 & 10 & 10 & 17 & 13 & 3.51 & $\begin{array}{l}\text { Somewhat } \\
\text { satisfied }\end{array}$ \\
\hline $\begin{array}{l}\text { Carrying out road works } \\
\text { speedily and efficiently }\end{array}$ & 6 & 19 & 21 & 4 & 0 & 2.32 & $\begin{array}{l}\text { Somewhat } \\
\text { dissatisfied }\end{array}$ \\
\hline 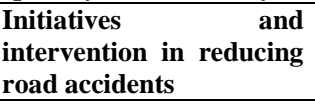 & 5 & 20 & 22 & 3 & 2 & 2.51 & $\begin{array}{l}\text { Neither } \\
\text { satisfied nor } \\
\text { dissatisfied }\end{array}$ \\
\hline Accident clean-up time & 11 & 21 & 14 & 6 & 1 & 2.34 & $\begin{array}{l}\text { Somewhat } \\
\text { dissatisfied }\end{array}$ \\
\hline 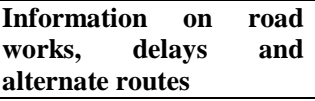 & 10 & 23 & 13 & 7 & 0 & 2.32 & $\begin{array}{l}\text { Somewhat } \\
\text { dissatisfied }\end{array}$ \\
\hline $\begin{array}{l}\text { Complaint redressal } \\
\text { system }\end{array}$ & 13 & 18 & 15 & 6 & 1 & 2.32 & $\begin{array}{l}\text { Somewhat } \\
\text { dissatisfied }\end{array}$ \\
\hline $\begin{array}{l}\text { Instant repair when } \\
\text { complain by public on } \\
\text { defects on the roads }\end{array}$ & 14 & 26 & 11 & 5 & 0 & 2.25 & $\begin{array}{l}\text { Somewhat } \\
\text { dissatisfied }\end{array}$ \\
\hline $\begin{array}{l}\text { Continuous clean-up of } \\
\text { dirt on the road surface }\end{array}$ & 7 & 15 & 23 & 8 & 0 & 2.60 & $\begin{array}{l}\text { Neither } \\
\text { satisfied nor } \\
\text { dissatisfied }\end{array}$ \\
\hline $\begin{array}{l}\text { Good defect (potholes, } \\
\text { cracks etc.) patching }\end{array}$ & 6 & 27 & 13 & 7 & 0 & 2.4 & $\begin{array}{l}\text { Somewhat } \\
\text { dissatisfied }\end{array}$ \\
\hline $\begin{array}{l}\text { Adequate attention to } \\
\text { maintenance activities }\end{array}$ & 9 & 28 & 9 & 6 & 1 & 2.28 & $\begin{array}{l}\text { Somewhat } \\
\text { dissatisfied }\end{array}$ \\
\hline
\end{tabular}

\subsection{Objective 4: Analyse the problems on road defect reporting system and documentation in KARMA} 4.6.1 Interview

Eight workers were selected from KARMA (targeted agency) in this research and both selected personals were interviewed. The significance of this interview is to further understand the nature of the organization as well as the problem facing in the agency's reporting system and documentation.

\subsubsection{Result of the interview}

Q1. How does the user's complains comes in to your agency?

The respondent answers comes in different form, 2 out 8 of the interviewed personal said that the complaint comes through mails and verbal reporting, the remaining 5 respondent also gave different answers, one of the respondent said that complaint are reported only when an accident happened, and the remaining four 
personal said that complaints are coming through a written request or complain by associations, groups, community leaders or road users.

Q2. How long does it takes to repair from the time that the defect is been reported by the road users?

Majority of the respondent said that the repair works carried out only when there is available fund and material to carry out the job (i.e. when the complainers reported their complain to the agency the agency will send their request to the government for provision of fund, which make them to stand still till government approved and provide the fund to the agency then repair works is carryout.)

Q3. When taking action on the defect reported by road users it is individual repair works of the defect reported in a particular area or it is accumulated repair works in different area?

Seven out of eight interviewed personals said that repair work is mostly an accumulated repair works, but sometimes when it is potholes it may be repaired individually depending on the urgency. Only one of the respondent said the repair is carry out individually.

Q4. Do you have your own crew for road inspection?

The entire respondent said that the agency have their own crew for road inspection which comprises of engineers, technician and labourers.

Q5. How many times are you inspecting the road for defect observation per year?

Four of the respondent said that the inspection of the roads is carryout once par year and three others said twice a year, while another respondent said that in his authority there are some certain staffs that are assigned to handle the maintenance work of which he has no authority to give this detail.

Q6. Do you have priority in selecting the defect for repair (e.g. Potholes listed as urgent. work, crack sealing as normal work etc.)?

Four of the interviewed personal said that, they have no priority in taking any maintenance repair of any defect is just a general maintenance. After accumulating the complaint from public or after inspection by the maintenance department a general maintenance and repair is carryout. Two other said that they do have priority in carryout the maintenance, while only one of the personal said that "in a matter of urgency potholes should be given more priority" which is an advice not the exert answer needed.

Q7. How many people are there in the organization?

Majority of the respondent said they have at least 40 to 60 personals which include engineers, technician, and labourers while one of the respondent said he doesn't know the exert number of staff they have.

Q8. What type of reporting system are you using (e.g. traditional or web based reporting System)?

All of the respond said that the agency is using traditional method of reporting system whereby pavement and traffic facility defects are discovered by patrol road engineers or road users. The agency used telephones to report and request maintenance activities. The defect inventories and M\&R activities are usually hand written or sometimes manually entered in a computer database.

\section{Conclusion And Recommendation}

The details of each objective achievement have been summarized in this part, and the conclusion of the study is as follows.

\subsection{Objective 1: Examine the types of road defect on Kano metropolitan roads.}

Pavement deterioration is the process by which distress (defects) develop in the pavement under the combined effects of traffic loading and environmental conditions. This defect or deterioration occurs can be cracks, surface deformation, disintegration (potholes, etc.) and Surface defects (bleeding, etc.). Therefore, from this study, it can be concluded that the significant road defect/deterioration occurred or observed on Kano metropolitan road among all the types of defects studied in this research are as below.

- Pothole with average index of 4.00 which is open occurred.

- Patching and utility cut patching/Reinstatement of utility openings (electricity, water, telecommunication etc.) with average index of 3.52 which is open occurred

- Edge cracks average index 3.76 which is open occurred

- Longitudinal with cracks average index 3.72 which is open occurred

- Depression with average index 3.52 which is open occurred 


\subsection{Objective 2: Explore the factors that contribute to the road defects}

Having looked through at the types of defect occurred on Kano metropolitan road in objective one. Similarly here, the factors that contributed to these defects have been determined in this research. However, there are many different types of causes of road deterioration. But according to the personals in the agencies (KARMA, KNUPDA, and Ministry of works) the significant causes of deterioration on Kano metropolitan road are as follows.

\section{- Effect of Cracks and Structural Failure}

The design and construction done usually in most of the Kano road are done either by the ministry or by those consultant that have inadequate knowledge on design or they may totally not have background on road work which lead to poor construction quality, thereby cause many effect like Structural failure of base/sub-base, Reflection of a shrinkage crack or joint in an underlying base, and Construction joint or shrinkage crack as found in this research.

\section{- Effect of Standards/Specifications and Policy}

One of the main problems examined in this research study on Kano metropolitan road is inadequate maintenance policy and standards that can help the agency to properly maintain the roads. The roads are rarely maintained and whenever maintenance is attempted is carried out in a substandard ways. Inadequate facilities of the road, lack of supervision or the supervision is sometimes by unprofessional personals or foreman who has less knowledge base, lack adequate laboratory facilities and trained laboratory manpower for the job, and no proper and adequate monitoring and control in the local construction process these are all factors that shows lack of Standards/Specifications and Policy in the agency which leads to serious deterioration of the roads.

\section{- Effect of Traffic Load and Volume}

Few or no remedies have taken by KARMA to avoid heavy traffic vehicles passing on the metropolitan roads. Many of heavy traffic sometimes enter residential areas and takes routes that are not allow for heavy traffic which cause serious deterioration of the roads.

\section{- Properties and Effect of Construction Conditions}

Inadequate compaction in surfacing or sub/base, inadequate strength (stability) in surfacing or base, and inadequate compaction, construction during wet or cold weather are also cause the deterioration of the roads.

\section{- Effect of Drainage System and Ground Water}

This is another horrible problem that is facing most of the road in Metropolitan especially the drainage system issues, most of the roads has inadequate drainage facilities that lead to Seepage of water through asphalt to break bond between surface and lower layers although high ground water level is not much experience.

\subsection{Objective 3: Evaluate the road user's satisfaction on the maintenance works carried out by KARMA}

This part of the study evaluates the road user's satisfaction of maintenance works carryout by KARMA agency on Kano metropolitan roads. Using average index as a measure of road user's satisfaction level, several factors have been drawn for this measurement, according to the analysis carried out, it is concluded that the road users are not satisfied with the following activities carryout by KARMA.

- Good defect (potholes, cracks etc.) Patching.

- Adequate attention to maintenance activities.

- Good maintenance / improvement of roads.

- Carrying out road works speedily and efficiently.

- Information on road works, delays and alternate routes.

- Instant repair when complain by public on defects on the roads.

- Overall riding/travel comfort on Kano Metropolitan Roads (e.g. Road surface appearance, Smoothness of the road and Road cleanliness)

\subsection{Objective 4: Analyse the problems on road defect reporting system and documentation in KARMA.}

After several interview conducted with the engineers and in depth review on some available documents to understand the reporting system of the KARMA agency the following point were concluded

- No proper way of addressing complaint to the agency, the complaints are only received through verbal or written which when received had to insert into computer manually. Though obviously there is no provision of computer for this task, the latter are kept in a file and sometimes may even be lost. 
- On keeping the complaint for repair the agency has to wait for several months till the government provide funds to the agency and this lead to additional accumulated complaints that makes some other complaints sent already by the public missed.

- Inspection of the roads is carryout once par year and the data gathered in the survey are documented manually which lead to several loss of the data.

- Inspections are carryout in traditional ways whereby pavement and traffic facility defects are discovered by patrol road engineers or road users.

\subsection{Comment and suggestion by respondents}

5.6.1 Comment and suggestion by respondent from KARMA, KNUPDA, and Ministry of works

Table 9 Comment and suggestion by respondents (KARMA, KNUPDA and Ministry)

\begin{tabular}{|c|c|}
\hline Respondent & Comment and suggestion \\
\hline 1 & $\begin{array}{l}\text { - } \quad \text { Provision of adequate funds for road maintenance by government } \\
\text { - } \quad \text { Establish ways of generating revenue from road users } \\
\text { - } \quad \text { Quality road Engineers should be given a chance to handle road maintenance issues } \\
\end{array}$ \\
\hline 2 & $\begin{array}{l}\text { - By ensuring proper loading (axial loading) base on the design so as to avoid depression } \\
\text { Avoid side trading to ensure uniform distribution of load over the carriage way to avoid } \\
\text { concentrated loading }\end{array}$ \\
\hline 3 & $\begin{array}{ll} & \text { Those responsible for road maintenance in KARMA has to be dedicated to their duties } \\
\text { - } & \text { Government should use standard during road project construction }\end{array}$ \\
\hline 4 & $\begin{array}{l}\text { - } \quad \text { Adequate supervision by expert should always be carry out by the agency } \\
\text { - } \quad \text { Use of experience personal }\end{array}$ \\
\hline 5 & - $\quad$ Proper supervision and following the ethics of the profession \\
\hline 6 & $\begin{array}{l}\text { - Government should provide adequate drainage facilities in all ongoing, future, and already } \\
\text { completed project } \\
\text { - The contractors and supervisors should concentrate in good construction practice and } \\
\text { standard }\end{array}$ \\
\hline 7 & $\begin{array}{l}\text { - Sensitization of government organizations handling construction and maintenance towards } \\
\text { effective routine and periodic repairs }\end{array}$ \\
\hline 8 & $\begin{array}{ll}\text { - } & \text { Proper supervision during construction and maintenance works } \\
\text { - } & \text { Provision of adequate drainage facilities } \\
\text { - } & \text { Provision of steel barricade to prevent heavy vehicles from using roads that are designed } \\
\text { just for lightweight vehicles }\end{array}$ \\
\hline 9 & $\begin{array}{ll}- & \text { To coordinate proper designs (standards) } \\
- & \text { Appropriate and highly coordinated supervision by professionals } \\
\end{array}$ \\
\hline 10 & $\begin{array}{ll} & \text { Government should provide adequate facilities to the agency } \\
\text { - } & \text { Routine maintenance has to taken } \\
\text { - } & \text { Enhance organizational structure of the agency }\end{array}$ \\
\hline
\end{tabular}

\subsection{Comment and suggestion by road users}

Table 10 Comment and suggestion by road users

\begin{tabular}{|c|c|}
\hline Respondent & Comment and suggestion \\
\hline 1 & $\begin{array}{l}\text { - KARMA should increase destination signs } \\
\text { - Create more alternative route road to reduced congestion so as to avoid overloads on the } \\
\text { roads }\end{array}$ \\
\hline 2 & $\begin{array}{ll}- & \text { We need proper checking and cleaning of the roads } \\
\text { - } & \text { Quick accident cleanliness } \\
\end{array}$ \\
\hline 5 & $\begin{array}{ll}\text { - } & \text { Effective supervision of the roads by KARMA personals } \\
\text { - } & \text { Rapid response when complain are being address to the agency }\end{array}$ \\
\hline 6 & $\begin{array}{ll}\text { - } & \text { Provision of adequate facilities for the maintenance works } \\
\text { - } & \text { Provision of KARMA at local government level }\end{array}$ \\
\hline 7 & $\begin{array}{l}\text { - } \\
\text { - } \\
\text { Alternative roots should be communicated and informed to road users during maintenance } \\
\text { works } \\
\text { - } \quad \text { Use of media as source to give awareness to road users on roads rules and regulations }\end{array}$ \\
\hline 8 & - $\quad$ Proper maintenance should be placed \\
\hline 9 & $\begin{array}{ll}- & \text { To restructure the KARMA agency } \\
\text { - } & \text { To employed both high skilled and unskilled workers } \\
\text { - } & \text { To provide modern equipment to KARMA } \\
\text { - } & \text { Constant supervision by government on the activities carryout by KARMA } \\
\end{array}$ \\
\hline 11 & $\begin{array}{l}\text { - } \quad \text { KARMA should have to always use qualitative materials in road maintenance } \\
\text { Government need to equip KARMA with necessary equipment for the execution of its } \\
\text { operations }\end{array}$ \\
\hline 13 & $\begin{array}{ll} & \text { Road construction be awarded to tested contractors } \\
\text { - } & \text { Carryout regular repairs/maintenance of the roads } \\
\end{array}$ \\
\hline
\end{tabular}




\begin{tabular}{|l|ll|}
\hline 14 & $\bullet$ & Government should additionally give more attention to the agency \\
\hline 15 & $\bullet$ & Improvement on quick action on public complain on road maintenance \\
\hline 16 & $\bullet$ & $\begin{array}{l}\text { Provision of international standard in road maintenance should be employed by KARMA } \\
\text { to enhance their efficiency and effectiveness }\end{array}$ \\
\hline 17 & $\bullet$ & $\begin{array}{l}\text { KARMA should give more attention whenever a complaint is addressed to them } \\
\text { They should give more awareness to road user's to understand those that have } \\
\text { responsibility in maintenance of the road so their complaints can easily be send to the } \\
\text { agency }\end{array}$ \\
\hline 18 & $\bullet$ & \begin{tabular}{l} 
Provide easy ways to send our complaints whenever need \\
\hline
\end{tabular} \\
\hline
\end{tabular}

\subsection{Recommendation from the study}

- Establishment of standard ways of addressing complaints by public (e.g. Mobile Road Monitoring and Reporting System and Web-Based Road Monitoring and Reporting System)

- Provision of standard data base for road maintenance data (complaints, accidents etc.)

- Provision of modern ways of inspection road defects (e.g. using remote sensing, road distress scanner vehicle, GPRS system etc.)

\subsection{Recommendation for future research}

Due to limited data gathered, the study conducted built only on literature reviews, interviews and data analysis on the collected data surveyed questionnaire. So there is limitation on the study conducted (i.e. the study is not conclusive). Nevertheless, there are other aspects to be studied for future research as follows.

a. Effectiveness of road maintenance management system

b. Proposed design for reporting and documentation system

c. Effectiveness of the maintenance organization

d. Study the design criteria of the roads in Kano metropolitan

e. Study and assess the repair work carryout by departmental or contractor

f. Study on the effectiveness of budget forecasting methods on the quality of the maintenance works carryout by the agency

\section{References}

[1]. M. Mubaraki, "Predicting deterioration for the Saudi Arabia Urban Road Network," University of Nottingham, 2010.

[2]. J. Archutowska and J. Pieriegud, "Effectiveness of National Roads Maintenance Management in poland,” Poland, 2012.

[3]. A. Ibochi, O. F.I, and O. J.A, "Development of a Road Maintenance Model (RMM) Using Geographic Information Systems for Road Maintenance in Nigeria: A Case Study of Abuja Phase 1 Road Network, Nigeria,” 2013.

[4]. A. Olatunji and I. A. Diugwu, "A Project Management Perspective to the Management of Federal Roads in Nigeria : A Case Study of Minna- Bida Road,” vol. 1, no. 4, pp. 54-61, 2013.

[5]. N. Okigbo, "Causes of Highway Failures in Nigeria," vol. 4, no. 11, pp. 4695-4703, 2012

[6]. S. Tarawneh and M. Sarireh, "Causes of Cracks and Deterioration of Pavement on Highways in Jordan from Contractors , Perspective," vol. 3, no. 10, pp. 16-27, 2013

[7]. B. L. Pflug and S. Oesch, "Moire applied to real-time inspection of highways," vol. 112, no. 2, pp. 163-171, 1986.

[8]. KGS, “Kano Executive Council Meeting,” 2015. [Online]. Available: http://www.kwankwasiyyaonline.org/. [Accessed: 23-Jan2015].

[9]. I. Fahad, "The need to keep Kano Moving," 2014. [Online]. Available: https://fahadkano.wordpress.com/the-need-to-keep-kanomoving/. [Accessed: 20-Jan-2014].

[10]. R. Sanusi, "Annual Abstract of Statistic , 2010 Federal Republic of Nigeria," 2010.

[11]. R. Okafor, I. Adeleke, and A. Oparac, "An Appraisal of the Conduct and Provisional Results of the Nigerian Population and Housing CENSUS of 2006," pp. 2199-2205, 2006.

[12]. Leadership newspaper, "Kano state road maintenance agency rehabilitates 42 township roads," 2015. [Online]. Available: http://leadership.ng/news/metro/402523/kano-state-road-maintenance-agency-rehabilitates-42-township-roads. [Accessed: 15Jan-2015].

[13]. J. Pallant, "SPSS Survival Manual. A step by step guide to data analysis using spss for windows.” p. $350,2007$. 